\title{
Improved Method to Estimate Oxygen Consumption, Diffusing Capacity and Blood Flow of Synovial Membrane
}

\author{
By E. Svalastoga, T. Kiar and J. Grønlund \\ Department of Small Animal Diseases and Clınical Practıce, \\ Royal Veterinary and Agricultural University, Copenhagen and \\ Department of Orthopaedic Surgery, Rigshospitalet, Copenhagen, and \\ Department of Physiology, Odense University, Denmark.
}

\begin{abstract}
Svalastoga, E., T. Kiær and J. Grønlund: Improved method to estimate oxygen consumption, diffusing capacity and blood flow of synovial membrane. Acta vet. scand. 1989, 30, 113-119. - The joint cartilage is depending on the oxygen diffusing from the capillaries of the synovial membrane through the synovial tissue and synovial fluid.

In the present study we describe a new method to calculate the diffusing capacity $\left(\mathrm{DO}_{2}\right)$, oxygen consumption $\left(\mathrm{VO}_{2}\right)$ and blood flow of the synovial membrane. The principle of the method is to perfuse the joint cavity with two salıne solutions, one with high and one with low oxygen and nitrogen partial pressures and to measure the oxygen and nitrogen partial pressures in the perfusate flowing out of the joint. Using a model of gas exchange between the joint and the membrane a set of equations was derived expressing the relationship between the blood flow, diffusing capacity and oxygen consumption and the oxygen and nitrogen flowing to and from the joint in the two different perfusion situations. In 12 rabbit knee joints we found a blood flow of $0.388 \mathrm{ml} / \mathrm{min}$ (SEM 0.027), $\mathrm{VO}_{2}$ of $0.495 \mu \mathrm{l} / \mathrm{min}$ (SEM 0.196 ) and $\mathrm{DO}_{2}$ of $0.024 \mu \mathrm{l} / \mathrm{min} /$ Torr SEM 0.003 (mean).
\end{abstract}

joint perfusıon; joint model; mass spectrometry.

\section{Introduction}

The joint cartilage is oxygenated by diffusion of $\mathrm{O}_{2}$ from the capillaries of the synovial membrane through the synovial tissue and joint fluid. The oxygen transport depends on the diffusing capacity and the rate of oxygen consumption of the tissue barriere between the capillaries and the cartilage. These parameters may be affected in osteoarthritis due to inflammation of the synovial membrane which is likely to increase the diffusion distance and the rate of oxygen consumption.

The present study describes a new method to estimate oxygen consumption, diffusing capacity and blood flow of the synovial membrane. The principle of the method is to perfuse the joint cavity with saline at a high and a low oxygen nitrogen partial pressures. At the low $\mathrm{PO}_{2}$ and $\mathrm{PN}_{2}$, oxygen nitrogen diffuse from the synovial capillaries to the perfusate and at the high partial pressure the flows go in the opposite direction. Using a simple model of gas exchange between the joint cavity and the synovial membrane a set of equations was derived for the relationship between on the one side the $\mathrm{O}_{2}$ and $\mathrm{N}_{2}$ flows at the high and the low $\mathrm{PO}_{2}$ and on the other side the oxygen consumption $\left(\mathrm{VO}_{2}\right)$, the diffusing capacity 
$\left(\mathrm{DO}_{2}\right)$ and the blood flow of the synovial membrane. $\mathrm{VO}_{2}, \mathrm{DO}_{2}$ and $\mathrm{Q}$ were determined by insertion of the measured $\mathrm{O}_{2}$ flows into these equations which were then solved using an iterative algorithm.

\section{Materials and methods}

\section{Theory}

The joint model used in the data analysis has 3 components: i) the joint cavity, ii) the synovial membrane and iii) the capillaries of this membrane. The joint cavity was perfused with saline equilibrated with 2 different gas mixtures. Mixture 1 consisted of atmospheric air with $0.96 \% \mathrm{He}$. Mixture 2 was pure He. When the joint cavity was perfused with either of these mixtures oxygen and nitrogen were exchanged between the perfusate and the capillary blood. The change in the $\mathrm{O}_{2}$ content of the blood multiplied by the blood flow is equal to the amount of oxygen removed from or added to the perfusate less the amount consumed by the synovial membrane:

$\left(\mathrm{CtaO}_{2}-\mathrm{CtvO}_{2}(1)\right) \cdot \mathrm{Q}=\mathrm{JO}_{2}(1)-\mathrm{VO}_{2}$

$\left(\mathrm{CtaO}_{2}-\mathrm{CtvO}_{2}(2)\right) \cdot \mathrm{Q}=\mathrm{JO}_{2}(2)-\mathrm{VO}_{2}$

where $\mathrm{CtaO}_{2}$ and $\mathrm{CtvO}_{2}$ are the oxygen contents in the arterial and venous blood and $\mathrm{Q}$ is the blood flow through the capillaries. $\mathrm{JO}_{2}$ is the oxygen flow from the perfusate and $\mathrm{VO}_{2}$ is the rate of oxygen consumption in the synovial membrane. The indices 1 and 2 refer to the 2 different gas mixtures. The oxygen content in blood is a function of $\mathrm{PO}_{2}$ (the oxygen binding curve):

$\mathrm{CtO}_{2}=\mathrm{f}\left(\mathrm{PO}_{2}\right)$

$\mathrm{JO}_{2}$ is equal to the difference between the oxygen contents in the inflowing and outflowing perfusate multiplied by the perfusion rate:

$\mathrm{JO}_{2}(1)=\mathrm{F} \cdot \alpha \mathrm{O}_{2} \cdot\left(\mathrm{PiO}_{2}(1)-\mathrm{PoO}_{2}(1)\right)$

$\mathrm{JO}_{2}(2)=\mathrm{F} \cdot \alpha \mathrm{O}_{2} \cdot\left(\mathrm{PiO}_{2}(2)-\mathrm{PoO}_{2}(2)\right)$

where $\mathrm{F}$ is the joint perfusion rate and $\mathrm{\alpha O}_{2}$ is the solubility of oxygen in the perfusate.
$\mathrm{PiO}_{2}$ and $\mathrm{PoO}_{2}$ are the oxygen partial pressures in the perfusate flowing in and out of the joint cavity.

Insertion of (3), (4) into (1) and (2) gives:

$\left(\mathrm{f}\left(\mathrm{PaO}_{2}\right)-\mathrm{f}\left(\mathrm{PvO}_{2}(1)\right) \cdot \mathrm{Q}=\right.$

$\mathrm{F} \cdot \alpha \mathrm{O}_{2} \cdot\left(\mathrm{PiO}_{2}(1)-\mathrm{PoO}_{2}(1)\right)-\mathrm{VO}_{2}$

$\left(\mathrm{f}\left(\mathrm{PaO}_{2}\right)-\mathrm{f}\left(\mathrm{PvO}_{2}(2)\right) \cdot \mathrm{Q}=\right.$

$$
\mathrm{F} \cdot \alpha \mathrm{O}_{2} \cdot\left(\mathrm{PiO}_{2}(2)-\mathrm{PoO}_{2}(2)\right)-\mathrm{VO}_{2}
$$

where $\mathrm{PaO}_{2}$ and $\mathrm{PvO}_{2}$ are the arterial and venous oxygen partial pressures.

A previous analysis of the described joint model (Svalastoga \& Gronlund 1985) has shown that the oxygen flow to or from the perfusate can be approximated by:

$$
\begin{gathered}
\mathrm{F} \cdot \alpha \mathrm{O}_{2} \cdot\left(\mathrm{PiO}_{2}(1)-\mathrm{PoO}_{2}(1)\right)= \\
\mathrm{DO}_{2} \cdot\left(\mathrm{PpO}_{2}(1)-\mathrm{PcO}_{2}(1)\right)+\mathrm{VO}_{2} / 2 \\
\mathrm{~F} \cdot \alpha \mathrm{O}_{2} \cdot\left(\mathrm{PiO}_{2}(2)-\mathrm{PoO}_{2}(2)\right)= \\
\mathrm{DO}_{2} \cdot\left(\mathrm{PpO}_{2}(2)-\mathrm{PcO}_{2}(2)\right)+\mathrm{VO}_{2} / 2
\end{gathered}
$$

where $\mathrm{PpO}_{2}=\left(\mathrm{PiO}_{2}+\mathrm{PoO}_{2}\right) / 2$ and $\mathrm{PcO}_{2}=$ $\left(\mathrm{P}\left(\mathrm{PaO}_{2}+\mathrm{PvO}_{2}\right) / 2\right.$.

When the joint is perfused with saline equilibrated with gas mixture 2 (without nitrogen and oxygen, nitrogen diffuses from the perfusate to the capillaries of the synovial membrane. Mass conservation for nitrogen gives:

$\mathrm{F} \cdot \alpha \mathrm{N}_{2}(\mathrm{P}) \cdot\left(\mathrm{PiN}_{2}(2)-\mathrm{PoN}_{2}(2)\right)=$

$\mathrm{Q} \cdot \alpha \mathrm{N}_{2}(\mathrm{~B}) \cdot\left(\mathrm{PaN}_{2}-\mathrm{PvN}_{2}(2)\right)$

where $\alpha N_{2}$ (P) and $\alpha N_{2}$ (B) are the solubilities of nitrogen in the perfusate and blood. assuming that $\mathrm{PN}_{2}$ in the outflowing perfusate equilibrates with the nitrogen partial pressure in venous blood $\left(\mathrm{PoN}_{2}=\mathrm{PvN}_{2}\right)$ gives:

$$
\begin{gathered}
\mathrm{Q}=\mathrm{F} \cdot \alpha \mathrm{N}_{2}(\mathrm{P}) \cdot\left(\mathrm{PiN}_{2}(2)-\mathrm{PoN}_{2}(2)\right) / \\
\left(\alpha \mathrm{N}_{2}(\mathrm{~B}) \cdot\left(\mathrm{PaN}_{2}-\mathrm{PoN}_{2}(2)\right)\right.
\end{gathered}
$$

Eqs. (6), (7), (8), (9) and (11) form a system of 5 equations with 5 unknowns: $\mathrm{Q}, \mathrm{PvO}_{2}$ (1), $\mathrm{PvO}_{2}$ (2), $\mathrm{DO}_{2}$ and $\mathrm{VO}_{2}$. The partial pressure of nitrogen and oxygen in the inflowing perfusate are identical to those of the gas mixtures and the partial pressures at the outlet can be measured. the arterial $\mathrm{PO}_{2}$ and $\mathrm{PN}_{2}$ can be respectively measured and 
calculated from the composition of the inspiration gas. The oxygen binding curve of blood was derived from Bartels \& Harms (1959). This system of equations were solved using an iterative technique to find the zero point of multidimensional non-linear functions. The program was written in FORTRAN $77^{1}$ and processed by an Olivetti M24 SP Personal Computer equipped with an 8087 coprocessor.

\section{Experiments}

The experimental procedure and setup are very similar to that of a previous study ( $\mathrm{Sva}$ lastoga \& Grønlund 1985). 12 rabbits were anaesthetized by an initial dose of pentobarbitone $(20 \mathrm{mg} / \mathrm{kg})$ which was supplemented when necessary. The rabbits were kept on spontaneous ventilation and breathed atmospheric air. Hence, the arterial nitrogen partial pressure is given by:

$\mathrm{PaN}_{2}=\left(\mathrm{P}_{\mathrm{B}}-47\right.$ Torr $) \times 0.79$

where $P_{B}$ is equal to the barometric pressure. Arterial blood samples were obtained from a catheter in the carotid artery. The skin over the infrapatellar and the medial collateral ligaments was anaesthetized (0.5 $\mathrm{ml}$ lidocaine, $20 \mathrm{mg} / \mathrm{ml}$ ) and a 20 gauge cannula was inserted into the joint cavity via the infrapatellar ligament. A second cannula was inserted into the medial femoro-tibial joint compartment through the medial horisontal approach and the joint cavity was flushed to remove synovia and debris. The rabbit was then moved into a box with a temperature of $37^{\circ} \mathrm{C}$ and the joint was perfused by an infusion pump (Harvard Apparatus, Millis, U.S.) at a rate of approximately $2.0 \mathrm{ml} / \mathrm{min}$ with $0.9 \%$ saline equilibrated with either of the 2 gas mixtures. The perfusate was led through a T-tube (Fig. 1) with a blood gas catheter (Lundsgaard et al.

\footnotetext{
${ }^{1}$ Program is available on request.
}



Figure 1. Experımental setup. For details see text and Svalastoga \& Gronlund (1985).

1980) connected to a mass spectrometer (VG MCROMASS, Middlewich, U. K.). The mass spectrometer in combination with the catheter enables continuous and simultaneous measurement of $\mathrm{PO}_{2}$ and $\mathrm{PN}_{2}$ in the perfusate. After attainment of steady $\mathrm{O}_{2}$ and $\mathrm{N}_{2}$ readings (usually within 5-10 min) an arterial blood sample was taken to measure $\mathrm{PaO}_{2}$.

\section{Results}

In the calculations $\alpha \mathrm{O}_{2}$ was set to 0.0326 $\mu / \mathrm{ml} /$ Torr. $\alpha \mathrm{N}_{2}$ (B) and $\alpha \mathrm{N}_{2}$ (P) were assumed equal and thus cancelled in eq. (11). We used the oxygen binding curve for rabbit blood reported by Bartels \& Harms (1959). The curve was digitized and incorporated in the computer program. Table 1 summarizes the results of the study. The first 5 columns show the measured values of $\mathrm{PaO}_{2}, \mathrm{PoO}_{2}$ and $\mathrm{PoN}_{2}$ in each of the experiments. Columns 6-8 show the calculated oxygen consumptions $\left(\mathrm{VO}_{2}\right)$, diffusing capacity $\left(\mathrm{DO}_{2}\right)$ and blood flow (Q).

\section{Discussion}

The validity of the calculated oxygen consumptions, diffusing capacities and blood flows depend on the magnitude of errors in the measured partial pressures of oxygen and nitrogen in the outflowing perfusate. 
Table 1. Estımated oxygen consumption, diffusing capacity and blood flow in synovial membrane of rabbits.

\begin{tabular}{|c|c|c|c|c|c|c|c|c|}
\hline Experıment & $\begin{array}{l}\mathrm{PaO}_{2} \\
\text { (Torr) } \\
\end{array}$ & $\begin{array}{l}\mathrm{PvO}_{2} \\
\text { (Torr) } \\
\end{array}$ & $\begin{array}{l}\mathrm{PoO}_{2} \mathrm{I} \\
\text { (Torr) }\end{array}$ & $\begin{array}{l}\mathrm{PoO}_{2} \mathrm{II} \\
\text { (Torr) }\end{array}$ & $\begin{array}{l}\text { PoN2 } \\
\text { (Torr) }\end{array}$ & $\begin{array}{c}\mathrm{VO}_{2} \\
(\mu 1 / \mathrm{m} \mathrm{In} / \mathrm{Torr})\end{array}$ & $\begin{array}{c}\mathrm{DO}_{2} \\
(\mu \mathrm{l} / \mathrm{m} \mathrm{n} / \mathrm{Torr})\end{array}$ & $\begin{array}{r}\text { Blood flow } \\
(\mathrm{ml} / \mathrm{min})\end{array}$ \\
\hline 1.000 & 68.300 & 87.13 & 115.990 & 28.340 & 96.500 & 0.103 & 0.036 & 0.393 \\
\hline 2.000 & 55.300 & 59.41 & 101.510 & 24.040 & 132.100 & 0.381 & 0.040 & 0.582 \\
\hline 3.000 & 86.600 & 109.36 & 127.160 & 30.420 & 96.800 & 0.014 & 0.034 & 0.436 \\
\hline 4.000 & 87.250 & 108.04 & 135.160 & 18.560 & 68.700 & 0.093 & 0.019 & 0.292 \\
\hline 5.000 & 69.200 & 79.65 & 128.870 & 16.310 & 87.100 & 0.093 & 0.020 & 0.384 \\
\hline 6.000 & 81.300 & 101.75 & 132.460 & 14.500 & 59.700 & 0.401 & 0.018 & 0.249 \\
\hline 7.000 & 58.500 & 59.78 & 113.900 & 0.720 & 78.600 & 1.991 & 0.019 & 0.325 \\
\hline 8.000 & 71.500 & 79.69 & 112.850 & 18.330 & 102.400 & 1.189 & 0.031 & 0.445 \\
\hline 9.000 & 46.900 & 48.20 & 142.090 & 8.800 & 95.700 & -0.606 & 0.007 & 0.430 \\
\hline 10.000 & 57.700 & 61.27 & 109.260 & 14.070 & 106.300 & 1.076 & 0.031 & 0.489 \\
\hline 11.000 & 57.700 & 61.38 & 121.730 & 8.900 & 73.900 & 0.744 & 0.019 & 0.317 \\
\hline 12.000 & 72.100 & 79.26 & 131.400 & 9.890 & 72.900 & 0.452 & 0.014 & 0.312 \\
\hline $\begin{array}{l}\text { Mean } \\
\mathrm{N}=12.000\end{array}$ & 67.696 & 77.877 & 122.698 & 16.080 & 89.225 & 0.495 & 0.024 & 0.388 \\
\hline STD & 12.355 & 20.584 & 11.584 & 8.240 & 19.077 & 0.649 & 0.010 & 0.091 \\
\hline SEM & 3.725 & 6.20 & 3.493 & 2.484 & 5.752 & 0.196 & 0.003 & 0.027 \\
\hline
\end{tabular}

Furthermore, the validity depends on to what extend such errors are amplified in the algorithms used to calculate $\mathrm{VO}_{2}, \mathrm{DO}_{2}$ and Q. To evaluate the importance of this error source we have altered the measured values of $\mathrm{PoO}_{2}(1), \mathrm{PoO}_{2}$ (2) and $\mathrm{PoN}_{2}$ (2) by \pm 20 and $\pm 10 \%$ and recalculated $\mathrm{VO}_{2}, \mathrm{DO}_{2}$ and Q. Figs. 2-4 show the effects of such errors.

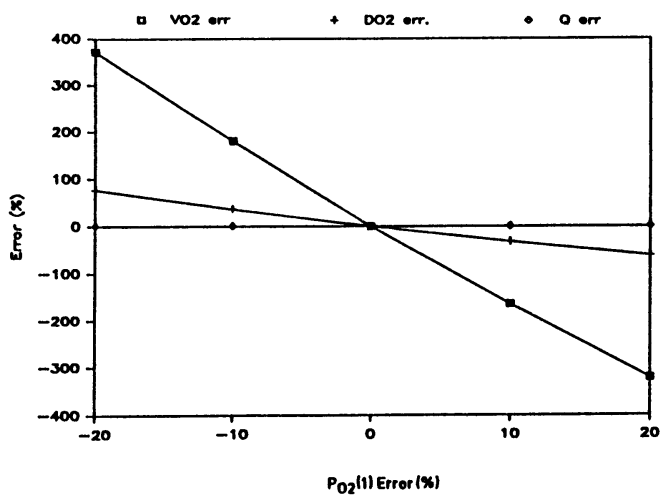

Figure 2. Effect on estimated $\mathrm{VO}_{2}, \mathrm{DO}_{2}$ and $\mathrm{Q}$ values of altering $\mathrm{PoO}_{2}(1) \pm 20 \%$.
The sensitivities to errors in $\mathrm{PoO}_{2}$ (2) and $\mathrm{PoN}_{2}$ are quite small whereas errors in $\mathrm{PoO}_{2}$ (1) cause large errors in $\mathrm{VO}_{2}$ and $\mathrm{DO}_{2}$ and can in fact cause the calculated oxygen consumption to become negative. Only one of the experiments showed a negative $\mathrm{VO}_{2}$. $\mathrm{PoO}_{2}(1)$ is accurately measured by the mass spectrometer because the instrument is cali-

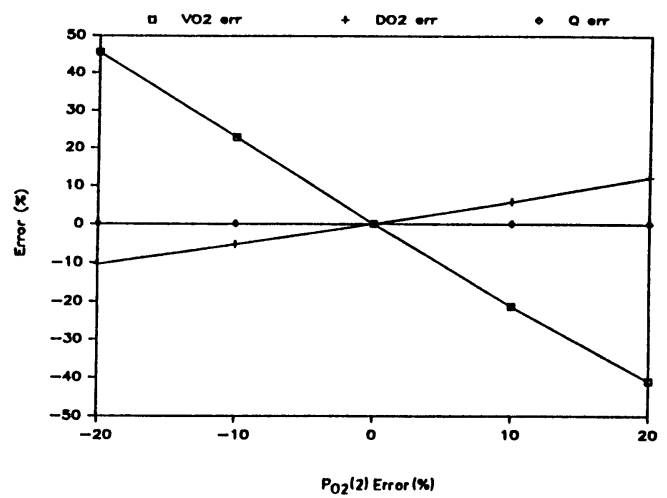

Figure 3. Effect on estimated $\mathrm{VO}_{2}, \mathrm{DO}_{2}$ and $\mathrm{Q}$ values of altering $\mathrm{PoO}_{2}(2) \pm 20 \%$. 

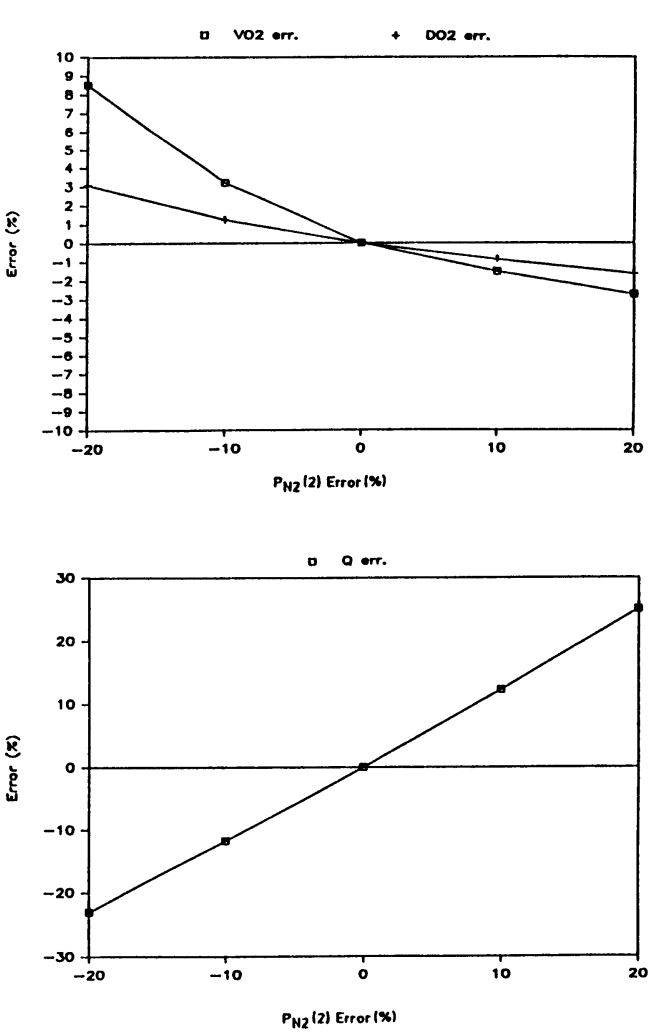

Figure 4. Effect on estimated $\mathrm{VO}_{2}, \mathrm{DO}_{2}$ and $\mathrm{Q}$ values of altering $\mathrm{PoN}_{2}(2) \pm 20 \%$.

brated in salt water saturated with atmospheric air which has an oxygen partial pressure $(\approx 150$ Torr) close the typical value of $\mathrm{PoO}_{2}$ (1) (Table 1). The accurate measurement of $\mathrm{PoO}_{2}$ (1) probably explains that only one of the experiments showed a negative $\mathrm{VO}_{2}$.

The other main source of error is the lack of complete equilibration between nitrogen in the outflowing perfusate and the venous blood. Fig. 5 shows the influence on the results of assuming that respectively $30 \%$, $20 \%, 10 \%$ and $5 \%$ of the intial $\mathrm{PN}_{2}$ difference between the inflowing blood and the perfusate remains between the outflowing

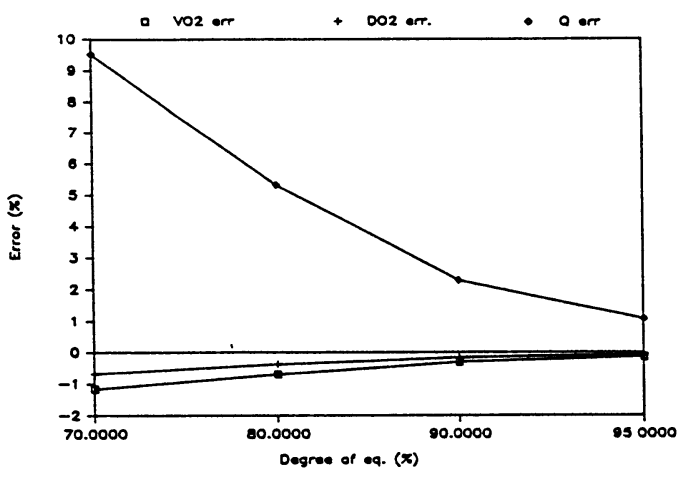

Figure 5. Influence on the estımated $\mathrm{VO}_{2}, \mathrm{DO}_{2}$ and $\mathrm{Q}$ values of assuming that respectıvely $30 \%$, $20 \%, 10 \%$ and $5 \%$ of the intial $\mathrm{PN}_{2}$ difference between the inflowing blood and the perfusate remains between the outflowing blood and perfusate.

blood and perfusate. It is interesting to note that the results are not critically dependent on the fulfillment of the assumption of the equilibration of nitrogen between outflowing perfusate and venous blood.

In a previous study (Svalastoga \& Grønlund 1985), we have determined the diffusing capacity and the rate of oxygen consumption in the synovial membrane using a method based on measuring flow of oxygen from the perfusate across the synovial membrane to the capsular capillaries. By altering the joint perfusion rate we obtained 63 sets of data on the $\mathrm{PO}_{2}$ in the outlet versus the perfusion rate in 14 rabbit knee joints. Using a least squares technique these data gave a single estimate on the $\mathrm{VO}_{2}$ and $\mathrm{DO}_{2}$. To determine the standard deviations of these estimates it was necessary to use a computer simulation based on a simplified statistical model. In the present study we obtained 12 individual values of $\mathrm{VO}_{2}$ and $\mathrm{DO}_{2}$ which allowed calculation of the standard deviations. In addition to providing an experimental estimate of the random variation in the calculated 
$\mathrm{VO}_{2}$ and $\mathrm{DO}_{2}$ values the new method has the advantage of giving an estimate of the blood flow. Finally, the assumption of identical oxygen partial pressures in the capsular arteries and capillaries is avoided. The results shown in Table 1 indicate that avoidance of this assumption is an important improvement because in most experiments the venous $\mathrm{PO}_{2}$ is far from the oxygen partial pressure in the effluent perfusate.

We have not been able to find data in the literature which are comparable to ours. The mean $\mathrm{VO}_{2}$ was found to be $47 \%$ and the mean $\mathrm{DO}_{2} 38 \%$ less than the estimates of the previous study. A possible explanation for these differences is the lack of equilibration of oxygen across the synovial membrane.

The partial pressure difference across the synovial membrane required to overcome the oxygen consumption can be estimated by insertion of $\mathrm{JO}_{2}=0$ into eq. (4) and (8):

$\mathrm{PO}_{2}(\mathrm{C})-\left(\mathrm{O}_{2}(\mathrm{JC})=\mathrm{VO}_{2} / 2 \times \mathrm{DO}_{2}\right.$

where $\mathrm{PO}_{2}$ (JC) is the oxygen partial pressure of the joint cavity in the case where the net oxygen flow across the synovial membrane is zero. Insertion of the mean values for $\mathrm{VO}_{2}$ and $\mathrm{DO}_{2}$ gives an oxygen partial pressure difference across the membrane of about 10 Torr. This value compared to the arterial value of approx. 68 Torr is small and leaves ample reserve for the oxygenation of the joint cartilage.

Our data on synovial blood flow of 0.388 $\mathrm{ml} / \mathrm{min}$ are difficult to assess because most other publications report flows in $\mathrm{ml} / \mathrm{min} / \mathrm{g}$. To compare our results with recent investigations of blood flow in the synovial membrane using radio labelled microsphere technique, we dissected the synovial membrane from 2 rabbit knee joints. In contrast to Phelps et al. (1972), we found it impossible to differentiate between the layers of the membrane. We were able to recover approx.
$1 \mathrm{~g}$ of synovial tissue and it was estimated that this amount corresponds to about half of the total amount of synovial tissue. This gives a synovial blood flow of approx. 20 $\mathrm{ml} / \mathrm{min} / 100 \mathrm{~g}$ for the rabbit knee joint. Using labeled microsphere technique in rabbit synovial membrane Hierton (1981) found a flow of $10 \mathrm{ml} / \mathrm{min} * 100 \mathrm{~g}$. Bünger (1987) reported a flow of $1 \mathrm{ml} / \mathrm{min} * 100 \mathrm{~g}$ in juvenile canine knee joint capsule, and Lucht et al. (1983) calculated a flow of $10 \mathrm{ml} / \mathrm{min} *$ $100 \mathrm{~g}$ in the juvenile canine hip joint capsule.

The clinical applicability of the new method has not been tested. However, it would be easy to perform the measurement under arthroscopic examinations because the arthroscope already includes facilities for infusion of salt water into the joint.

\section{References}

Bartels $H$, Harms $H$ Sauerstoffdissoziationskurven des Blutes von Saugetieren. (Oxygen dissociation curves in mammal blood). Pflügers Arch. 1959, 268, 334-365.

Bunger $C$. Hemodynamics of the juvenile knee. Acta Orthop. Scand. 1987, 58, Suppl. 222.

Hierton $C$ Effects of Indometacin, Naproxen and Paracetamol on Regional Blood Flow in Rabbits: A Microsphere Study. Acta pharmacol. et toxicol. 1981, 49, 327-333.

Lucht $U$, Bünger C, Krebs B, HJermınd J, Bülow $J$ Blood flow in the juvenile hip in relation to changes of the intraarticular pressure. Acta orthop. scand. 1983, 54, 182-187.

Lundsgaard JS, Jensen B, Grønlund $J$ Fast-responding flow-independent blood gas catheter for oxygen measurement. J. appl. Physiol. 1980, 48, 376-381.

Phelps P, Steele AD, McCarty DJ. Significance of xenon-133 clearance rate from canıne and human joints. Arth \& Rehum 1972, 15, 360-370. 
Svalastoga E, Gronlund $J$ Experimental osteoarthritis in the rabbit. II. A new method to estimate the oxygen consumption and diffusion capacity in the synovial membrane of the knee. Acta vet. scand. 1985, 26, 326-339.

\section{Sammendrag}

Forbedret metode til at måle iltforbrug, diffusionskapacitet og blodgennemstrømning i synovialmembranen

Ledbruskens 1ttforsyning er afhængig af diffusion fra synovialmembranens kapillærer samt transport gennem synovi. I nærværende arbejde redegøres for en metode til at bestemme synovialmembranens blod flow $(\mathrm{Q})$, diffusions kapacitet $\left(\mathrm{DO}_{2}\right) \mathrm{og}$ metabolisme $\left(\mathrm{VO}_{2}\right)$ Princippet 1 metoden er at perfundere leddet med to saltvandsopløsninger, én med lavt og én med højt indhold af ilt og kvælstof. Ved anvendelse af en model for gasudveksling genereres ligninger, der udtrykker forholdet mellem $\mathrm{Q}, \mathrm{VO}_{2}$ of $\mathrm{DO}_{2}$ og 1t- og kvælstofflow til og fra perfusionsvæsken.

Ved undersøgelse af 12 kanınknæled fandt vi $\mathrm{Q}=$ $0.388 \mathrm{ml} / \mathrm{min}$ (SEM 0.027), $\mathrm{VO}_{2}=0.495 \mu \mathrm{l} / \mathrm{min}$ (SEM 0.196) og DO $2=0.024 \mu \mathrm{l} / \mathrm{min} /$ Torr (SEM 0.003) (mean).

(Recelved March 22, 1988, accepted June 29, 1988)

Reprints may be requested from: Eiliv Svalastoga, Department of Small Anımal Diseases and Clinical Practice, The Royal Veterinary and Agricultural Unıversity, Copenhagen, Bülowsvej 13, DK-1870 Frederıksberg C, Denmark. 
